\title{
Erratum to: Botryosphaeriaceae species associated with stem canker, die-back and fruit rot on apple in Uruguay
}

\section{Leonardo Delgado-Cerrone • Pedro Mondino-Hintz • Sandra Alaniz-Ferro}

Published online: 26 December 2016

(C) Koninklijke Nederlandse Planteziektenkundige Vereniging 2016

\section{Erratum to: Eur J Plant Pathol \\ DOI 10.1007/s10658-016-0949-Z}

In the title "Botryosphariaceae species associated with stem canker, die-back and fruit rot on apple in Uruguay" the word Botryosphariaceae is incorrect, the correct is "Botryosphaeriaceae".

The online version of the original article can be found at http://dx/doi.org/10.1007/s10658-016-0949-z

L. Delgado-Cerrone · P. Mondino-Hintz •

S. Alaniz-Ferro $(\square)$

Departamento de Protección Vegetal, Facultad de Agronomía, Universidad de la República, Garzón 780, 12900 Montevideo, Uruguay

e-mail: salaniz@fagro.edu.uy 